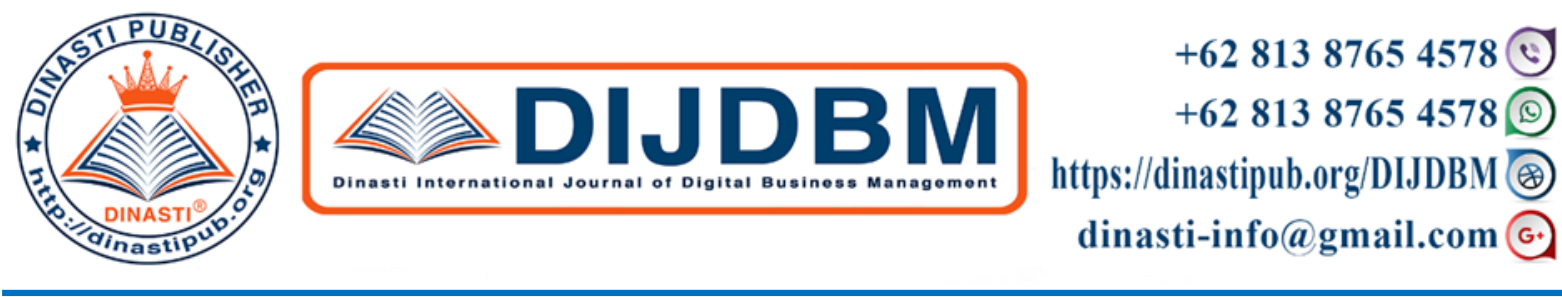

\title{
ANALYSIS OF FAMILY BUSINESS DEVELOPMENT MODEL BASED ON BUSINESS MODEL CANVAS (CASE STUDY IN CV. MXY)
}

\section{Frendy Hermawan}

Universitas Mercu Buana, Jakarta, Indonesia

ARTICLE INFORMATION
Received: $22^{\text {nd }}$ May 2020
Revised: $20^{\text {th }}$ June 2020
Issued: $23^{\text {th }}$ August 2020
Corresponding author:
Frendy Hermawan

E-mail:

frendyh.mpl@gmail.com

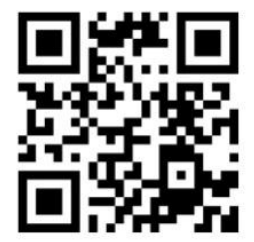

DOI:10.31933/DIJDBM
Abstrak: Generator set (genset) is one of the solution on overcoming the problem of electricity in Indonesia. CV. MXY, which was established in 2009, is a genset spare parts distributor company headquartered in Jakarta. As a company that belongs to the middle-scale family business group, since its foundation CV. MXY has never had a concept of its business model. Amid the turbulent global economic situation, and the consequences of the Covid-19 pandemic. The company feel the need to make internal improvements in the organization. This was done in order to survive in a very competitive market. The purpose of this research is to identify and design a business model of CV. MXY based on the business model canvas and provides recommendation to companies, with due regard to the condition of family management. This research also to provide insight and alternative choices for family business that are trying to develop their business models. The research method used is a descriptive method based on case studies. Research was conducted in Jakarta in 2020 with data collection techniques carried out through interviews, field observations and library research. From the result of the research can be designed a business model CV. MXY based on business model canvas. In addition, the business model canvas is a simple and easy-to-understand solution as a first step in creating a business model.

Keyword : Business model canvas, family business, business model

\section{INTRODUCTION}

As an archipelagic nation, Indonesia has long had major problems related to the distribution of electricity power. The large number of islands and the vast territory of Indonesia, making the State Electricity Company (PLN) assigned to provide electrical energy sometimes difficult to meet the need for electrical energy in achieving its economic value. 
Another problem is that there are still quite frequent outages due to irregularities in PLN's internal management. Another alternative that is often used in overcoming electrical problems is the use of Generator Sets (Gensets). In addition to being used to overcome the problem of electricity in areas with relatively limited electrical energy demand or in remote areas, it is also usually used as a back up of electricity when there is a power outage. There is no exact data that shows the total sales of Genset units throughout Indonesia, because the Genset product range, brands and players in this business are very numerous.

In order for the Genset to operate optimally, of course support for the availability of spare parts is needed. There are many of products and brands of spare parts generators on the market. One of the companies engaged in the distribution of spare parts generators is $\mathrm{CV}$. MXY. CV. MXY is a generator spare parts distributor company headquartered in Jakarta. Specializes in selling spare parts for Cummins ${ }^{\circledR}$ brand generators, both original products from Cummins ${ }^{\circledR}$ and replacement product parts. For current parts replacement products $\mathrm{CV}$. MXY sells spare parts under the AFA® brand from the USA and several brands from China. Almost all spare parts products sold by CV. MXY is an imported product.

CV. MXY is a family-run company, or better known as a family business. Operating since 2009, CV. MXY managed to record sales growth above double digits every year in the period 2009-2018. Only in 2019, CV. MXY noted stagnant sales growth and is likely caused by a very tight competition situation, declining demand due to Indonesia's economic conditions that tend to weaken, and due to other factors. To anticipate the challenges of the rapidly changing times, since the past year CV. MXY feels the need to adapt to the strategic plan and business model going forward. So far, CV. MXY has never made a concept of a business strategy, and the company runs based on what is decided centrally by the leadership of the company, and is assisted by subordinates of manager classmates who still have family relations with the leadership.

Small and medium-sized companies must have a strategy in order to produce a competitive advantage, Umar (2018). This is because competitors will always do product improvisation. If the company does not make changes, the company will be left behind compared to its competitor, Umar (2018). Due to limitations in terms of resources, CV. MXY is looking for a business model that is simple, easy to understand and accepted by all parties in the company in order to maintain the sustainability of the company. One alternative choice for the business concept of CV. MXY is using the business model canvas. Introduced by Alexander Osterwalder and Yves Pigneur, the business model canvas sparked a concept of simplifying business concepts that could be applied in all types of industries.

Although there are some criticisms of the application of the business model canvas, but the business model canvas is still suitable for use by novice entrepreneurs or those who have never developed a business model, Ching (2013).

The aim of this research can be stated as follows:

1. To understand, design and map the indicators that must be owned in building a business using a business model canvas, in this case using a case study on a company that already exists, but has never designed a concept of the business model.

2. To provide recommendation to the management of CV. MXY in order to develop the company's business model, so that companies can take advantage of all the potential 
that exists to achieve competitive advantage. The recommendation given was also adjusted to the condition of the company's management which until now was a family-business company.

The benefits that can be obtained from this research other than as a learning tool are in terms of adding insight and alternative choices for family businesses that might be looking for business models in business development.

\section{LITERATURE REVIEW}

Family businesses are the main pillars of the economy in almost all the world. These businesses make a major contribution to job creation. Many successful multinational companies started their business from a family business, Kaur (2019). Besides having its own strengths, there are also potential weaknesses in this business. Two things that are often the main obstacles in a family business are:

1. The company is difficult to develop, because the company is not managed professionally. Appointment of employees is based more on closeness and trust, compared to employee competence.

2. Family conflicts often occur because of communication constraints that do not work, a sense of excessive tolerance, which can ultimately weaken the company.

Business Model Canvas (BMC) is a business model that consists of 9 (nine) blocks of business activity areas, which have the goal of mapping strategies to build a strong business, so that they can win the competition and succeed in the long run. This BMC is characterized by nine block models which, when put together, will become a single business unit, namely: customer segments, value propositions, channels, customer relationships, revenue streams, key resources, key activities, key partnerships, cost structure.

The stages in preparing BMC according to Osterwalder in the PPM Management Team (2012), are as follows :

1. Define Customer Segments.

Customer segments contain who is the company's customer?. Why customer segments? Because only profitable customers will support the company.

2. Determine Value Propositions.

Value propositions contain the uniqueness of the product / service promised by the company to the targeted customer segments. Companies need to educate targeted customer segments, so they are willing to accept the value propositions offered.

3. Define Channels.

Channels explains how companies communicate, deliver, and interact with their customers. Success in activities in this channel block is largely determined by the effectiveness of the key resource blocks, key activities, and key partnerships because it plays a role in supporting the realization of the activities in these channels.

4. Define Customer Relationships.

Customer relationships is how much the company's activities maintain relationships with old customers, and how actively the company captures new customers and increases sales to old customers.

5. Determine Revenue Streams. 
Revenue streams explain where sources of income are earned by the company. This block will be successful in bringing funds into the company if backstage activities such as the key resources block, key activities and key partnerships can be managed properly and efficiently.

6. Determine Key Resources.

Key resources describe what resources companies need to produce products, for example, need labor, materials, money, and others.

7. Determine Key Activities.

Key activties explain what activities are needed to produce the company's products or services. For example there are activities of packaging, branding, marketing, and others.

8. Define Key Partnerships.

Key partnerships contain any partner that the company collaborates with to run the company. For example a network of suppliers and partners.

9. Determine the Cost Structure.

Cost structure contains the costs that are formed when the company produces and markets products / services. Efficiency in managing the elements in the back stage is very necessary to maintain the optimal cost structure.

\section{RESEARCH METHOD}

The research method used in this research is descriptive method based on case studies. Where descriptive research is research that explains a phenomenon as it is, Ali (2015). The purpose of this study is to present a profile or explain aspects that are relevant to a phenomenon studied from the perspective of an individual, organization, industry and other perspectives, Ali (2015). Case study is a study in which the researcher explores a particular phenomenon (case) in a time and activity (program, event, process, institution or social group) and collects detailed information using various data collection procedures over a certain period, Ali (2015). This research was conducted in 2020. The data collection techniques of this study used 3 methods, namely: interviews, field observations, and library research.

\section{Depth Interview}

In-depth interviews were conducted with all stakeholders in the CV. MXY. In addition to getting a complete picture of the company's activities, it is also carried out to explore deeply about family factors that influence company decisions. So the recommendations given in connection with this research can be accepted and applied by the company. The parties interviewed in this study were: Commissioner, President Director, Operations Director, Sales and Marketing Manager, and Finance and Accounting Manager. The five people interviewed all still have family relations.

\section{Field Observation}

Field observations were made to support the findings of the interviews and to further explore the company's activities. In addition, through observation in the field, it can help in 
providing final recommendations that are suitable for implementation in the corporate environment.

\section{Library Research}

This research was conducted to collect secondary data, both of which have been recorded in the form of writings of experts in their fields, research reports and research journals that have existed beforehand. Sources of data obtained either from books or by utilizing internet search facilities.

\section{Data Analysis}

After all the required data is collected, then the data is analyzed and compared with the data obtained from existing library research. For data that still needs confirmation, a repeat interview is conducted, so that in the end a conclusion is reached. The results of the analysis are the identification of elements in the existing Business Model Canvas (BMC) and recommendations for improvement that need to be made.

\section{RESULT AND ANALYSIS}

From the results of interviews conducted with the President Director and Commissioner CV. MXY, there are a number of things is the basis for why companies feel the need to improve their business model strategies, as follows :

1. An increasingly competitive competitive situation.

It must be realized from year to year, any business faces an increasingly competitive competition situation, this is also quite felt in the generator spare parts business. This is one of the effects of economic globalization and the progress of the times, especially in the field of information technology. Information about the market can be so easily accessed. This was also felt by CV. MXY, and is one of the causes of stagnant sales growth in 2019 compared to 2018.

2. Companies need to be managed more professionally so that they can develop more. This was realized by the leadership of CV. MPL, that many decisions and initiatives to innovate have to wait for decisions from above. Delegation of authority is still lacking, so many decisions are sometimes considered late. To be able to develop, CV. MPL needs to make a mapping of the problems that arise and their solutions, as well as rearrange what is the advantage of the business being run at this time.

3. Prepare for the leadership transition.

The company is now entering its 11th year and looking at the age of its current leadership, in the next 5-10 years the company must be prepared to make a leadership transition. In order for the leadership baton to continue, business owners want improvements in their governance and business model strategies. During this time, there are many overlapping responsibilities, causing inefficient companies. It is expected that the 2 nd generation, entrusted with the responsibility of leading the company, has inherited a company that has been better managed. So the company can be managed more easily, and maintained its sustainability. Or it can also develop into bigger than before. 
Based on the Business Model Canvas (BMC) concept, this reseach do identification of BMC elements in CV. MXY, for further discussion together with existing stakeholders. The results are then analyzed so that recommendations can be given for things that need improvement. The final recommendations given in this study are then conveyed, and the final recommendations given also take into account the family business factors that underlie the way of decision making in the company. The following are nine elements of BMC from the results of identification, analysis and recommendations that can be given for CV. MXY.

\section{Customer Segments}

Customers of CV. MXY is grouped into two major groups, namely: Suppliers and End Users. Suppliers here are traders who buy products for resale to end consumers. Whereas end users are users of direct products. From the evaluation of sales data CV. MXY in 2019, obtained $67 \%$ of the portion of sales contributed by the supplier group, and $33 \%$ contributed by end users. Of the $33 \%$ of end-user sales obtained through sales to companies engaged in the following business fields as table 1 .

Table 1. Profile of End User Customer Business Fields

\begin{tabular}{clc}
\hline No. & Business Field & Percentage of Sales \\
\hline 1 & Marine Industry & $31 \%$ \\
\hline 2 & Genset Rental Company & $22 \%$ \\
\hline 3 & Mining Company & $18 \%$ \\
\hline 4 & Forestry and Plantation Company & $11 \%$ \\
\hline 5 & Building and Office Management & $10 \%$ \\
\hline 6 & Others & $8 \%$ \\
\hline & TOTAL & $100 \%$ \\
\hline
\end{tabular}

But there are 2 other things that must be understood related to the above conditions:

- For every sale to the supplier, CV. MXY provides a sales discount of $5 \%$ of the selling price, while sales to the company's end user do not provide a discount. From here automatically profit margins obtained through sales to end users are greater than to suppliers.

- As technology advances, consumers in various regions will find it easier to get product information including who sells the product in Indonesia.

For this reason, CV. MXY must maintain the sales segment to the two groups above. Although the profit margins of sales through suppliers are smaller, but taking into account the vastness of the territory of Indonesia, and CV. MXY only has a single office in Jakarta, a value of $5 \%$ discount is considered still reasonable, to stimulate suppliers in selling $\mathrm{CV}$. MXY products. For the end user segment, CV. MXY focuses on customers from the marine industry, mining company, genset rental company, taking into account the following conditions belows :

- Average Genset users from the building and office management and the forestry and plantation sectors use the generator only as a backup power source. Generators are only used when the main power supply source is dead.

- Unlike the other three industries, they use generators as the main source of electricity, so the demand for spare parts is more routine and more. 


\section{Value Propositions}

A suitable value proposition was developed for CV. MXY are :

- One stop shopping concept spare parts.

This one stop shopping concept is considered appropriate because CV. MXY has a complete product range for Cummins ${ }^{\circledR}$ generator parts. Starting from the original $1^{\text {st }}$ class original parts from the Cummins ${ }^{\circledR}$ factory, $2^{\text {nd }}$ class replacement parts under the AFA ${ }^{\circledR}$ brand from USA, $3^{\text {rd }}$ class replacement parts which are Chinese products, all of which are available. Customers just need to choose which products fit the needs and budget.

- Value of trust.

Trust is an important factor in building today's spare parts business. This is because a lot of counterfeit spare parts products on the market. And in this case CV. MXY has taken the momentum to commit to not selling counterfeit spare parts products, and prioritizes honesty in informing the products being sold.

- Good customer service support.

Customer service is here in the form of purchasing consultations and after-sales spare parts support. Many problems in the field are found because the technician incorrectly read the part book to see the number of spare parts needed or the company does not have a part book. CV. MXY can help in providing solutions because it invests in special software, so as long as the name plate of the generator unit is still available, part books can be accessed at the CV. MXY office. This is very helpful for customers to make a mistake in ordering spare parts. In addition, with considerable technical experience, technical staff CV. MPL can help provide consultancy in choosing which vital parts must use $1^{\text {st }}$ class spare parts and which can use $2^{\text {nd }}$ class spare parts and so on.

Related to the value propositions CV. MXY guarantees certain spare parts according to the manufacturer's requirements. This is sometimes not conveyed to customers, due to the lack of trained HR to assess warranty conditions. To provide more value to customers, it is better if the warranty is delivered to the customer, by clearly including the warranty conditions and the clear claim and guarantee period. Besides that, CV. MXY must be consistent with carrying out predetermined value propositions.

\section{Channels}

To distribute their products, CV. MXY have their own delivery team and vehicle facilities for the city. Besides that, most customers also come to take what they buy themselves. For distribution outside the city is done by using the services of forwaders. The important thing for CV. MPL is possible to start making and choosing a list of forwaders partners, because in addition to facilitate payment methods, shipments from CV. MXY will be prioritized more in shipping from Jakarta, as well as shipping to the customer's address.

Channels of marketing and sales communication CV. MXY is done through direct interaction between marketing or sales staff and customers through regular visits, telephone calls, whatsapps, websites, and through social media.

Quoting Haryanto's article (2020), based on the latest We Are Social report, in 2020 there are an estimated 175.4 million internet users in Indonesia, this represents $64 \%$ of 
Indonesia's population, which collected 272.1 million people. In addition there are 160 million social media users or around $54 \%$ of Indonesia's population. Based on the foregoing CV. MXY must support to improve its marketing communication channels through social media, be it through Instagram, Facebook, Twitter or YouTube channels. Specifically in communicating new company products.

In addition, quoting from Putri (2020), 53\% of the Indonesian population has already spent online. CV. MXY should start trying to try online sales channels. There is indeed a challenge because these generator sets are specific items, and there are a lot of items. But CV. MXY can start selling consumable or fast moving spare parts in online platform. So that it can be a learning tool, and at any time when everything is switched to an online platform, $\mathrm{CV}$. MXY is ready and has experience with it.

These two things should underlie the CV. MXY, why you should optimally use social media and sales through online platforms.

\section{Customer Relationships}

Identification of the customer relationships program that has been carried out so far, it was found that so far the company regularly holds "customer appreciation programs" in the middle of each year and at the end of the year by providing sales discounts greater than usual. In addition, the company also routinely distributes souvenirs related to products sold at the time of religious holidays, company birthdays in order to get closer to customers. Customer relationships CV. MXY is run with the aim of:

- Retain old customers.

- Expand the market by finding new customers.

- Acquire customers from competing companies.

Related to customer relationships CV. MXY should be more active in promotional activities by participating in exhibition activities related to generators and should start thinking about building Customer Relationship Management (CRM). With a CRM approach, the company's customer relations program will be more targeted and measurable in communicating the best value in the company. In addition the company can take advantage in order to strengthen relationships between customers and the company, which in turn can increase customer loyalty.

\section{Revenue Streams}

All revenue streams of CV. MXY comes from the sale of Genset spare parts products and in Indonesian Rupiah (IDR). 35\% of sales of CV. MXY is done in cash, while the rest is done on credit with a tempo of 30-60 days. To get a credit facility, customers must apply for credit and include a number of terms and guarantees before being approved.

Regarding revenue streams, given the turbulent world economic situation in the past year and added to the current Covid-19 pandemic, it has an impact on almost all sectors. This is also related to the ability to pay the customer's company for accounts receivable that are due. To overcome this, CV. MXY prioritizes cash sales. Or temporarily tighten or stop providing credit facilities to new customers, review credit facilities granted to 20-40 days and tighten the collectibility of receivables that are past due. 


\section{Key Resources}

Physical resources owned by the company consist of office space and its facilities, spare parts storage warehouse, operational vehicles that support the company's operations. Office space along with facilities and warehouses so far have been utilized optimally, and rejuvenation of operational vehicles has also been running in support of the company's operations.

Human Resources (HR) that support the sustainability of CV. MXY is 34 people, with various levels of education and positions. But the use of HR in the corporate environment CV. MXY feels not optimal, because there are still many concurrent positions, overlapping job descriptions. To support the company's activities, CV. MXY needs to reform the company's organizational structure, and reinforce the job description of each section and employee.

Other resources at this time the company already has an Importer's Identification Number (API) and has obtained a green line facility from the Directorate of Customs and Excise. This green line facility facility must be maintained, while still correctly reporting imported goods. Because besides the ease in the process of releasing goods, this is also related to the efficiency of import costs.

\section{Key Activities}

Key activities are the main activities carried out by the company in order to produce products or services effectively. Observation of key activities from CV. MXY consists of:

- Procurement activities.

Goods procurement activities are usually carried out through import procurement by $90 \%$ and local procurement by $10 \%$. These activities include the process of buying requests, bidding requests, order processes, until spare parts are well received at the warehouse.

- Sales activities

Sales activities start from offering price, receiving orders, to ensuring the delivery process until received without any complaints by the customer. This activity involves the important role of the sales staff.

- Delivery or shipping activities.

This activity ensures that spare parts can be received by customers in appropriate quantities and in good condition. If the sale is done in cash, then the shipping activity can be carried out after the funds are received by the company. If the sale is done on credit, shipping can be done first and then billing activities can be carried out.

- Billing activities.

This activity involves the collection of receivables that are past due, for sales made on credit. This is an important activity related to the company's cash flow needs.

From the four activities mentioned above, overall the important role of collective cooperation between the inside of the company is seen. For this reason, the company must give emphasis to all activities without obstacles, so that they can support each other for the sake of company efficiency. 


\section{Key Partnerships}

The key partnership here is a network of suppliers and partners that make business processes work. Identification of key partnerships from CV. MXY, are as follows:

- Spare parts suppliers.

CV. MXY has a partnership relationship with suppliers in Jakarta and some region in Indonesia. This was done in order to expand the spare parts marketing network. CV. MXY relies on suppliers in the regions to expand its product marketing network.

- Forwaders.

In supporting the smooth flow of imported goods. And also the delivery of spare parts from Jakarta to the regions.

- Manufacturing partners.

Both principal holders of imported brands and local manufacturers. Overseas suppliers are the company's main partners, because the quality of products and prices are more competitive, following the desires of consumers. Whereas local supplier partners are needed in order to procure spare parts in a sudden situation, and non-vital supporting spare parts that can be obtained at competitive prices.

- Importing partners.

The importer partner is important for the company because its spare parts sales are unpredictable and the procurement time for imported goods is relatively long. To cover the shortage of supply, it can be done by buying from fellow importers partners. There is a kind of unwritten agreement that the price of fellow importers will be cheaper than their selling price in the market.

Partnerships with key supporting elements of the company are very important in supporting company performance. Relationships must be based on honesty, mutual trust and support. And this can be done by continuing to develop a good partnership pattern, so that it can support the company's goals.

\section{Cost structure}

Cost structure associated with all expenses incurred by the company to be able to produce a product that is ready to sell. These expenses and costs include:

- Company operational costs,

Operational cost which can include employee salary, electricity, telephone, vehicle and building maintenance, stationery, licensing related to company legality and others.

- Procurement of spare parts as merchandise, both imported and local.

This is the biggest expense of the company, because the company does not produce goods ready to sell, but through procurement from suppliers or manufacturing company.

- Income tax and import duties on imported goods.

The income tax on imported goods is $2.5 \%$ of the value of the goods, while the import duty on generator spare parts is $5 \%$ of the value of the goods. Spare parts imported from the USA must pay a full import duty of $5 \%$. Whereas spare parts imported from China, due to the cooperation agreement with the ASEAN region with China, there 
are those who get $0 \%$ exemption from import duty. The term of this condition that they must submit proof of form E. Form E contains a statement regarding the certificate of origin of the country of origin, as a condition of exemption from import duties.

- Shipping costs .

Shipping costs are import and local shipping costs. Generally the import process is carried out, the price offered based on FOB port of origin. So, CV. MXY must pay shipping costs, unloading fees, stacking costs, demmurage cost and trucking fees from the port to the warehouse owned by CV. MXY. In addition local shipping costs, consisting of shipping costs that are partially borne by the company and the cost of packing spare parts.

- Promotional costs.

Promotional costs here include the cost of procuring brochures, promotional content such as banners, paid advertising through social media, as well as providing souvenirs for customers.

In order to continue to exist, CV. MXY must do efficiency in reducing all costs incurred, by utilizing the potential of existing strengths. Some things that should be emphasized include:

- Very common in China, many new spare parts factories have sprung up, utilizing the convenience of government facilities. Companies must pay attention by continuing to look for the best suppliers in China, for example by regularly visiting exhibitions held in China. This is done to get the best price

- Companies must be able to maximize import duty relief facilities, by asking suppliers in China to issue form E properly. Because sometimes found due to supplier negligence, form $\mathrm{E}$ is not recognized, so $\mathrm{CV}$. MXY must pay import duties and administrative fines.

- With the imported green belt facility, companies can reduce the substantial shipping costs associated with the accumulation costs that must be incurred.

- Because the payment of imported spare parts uses foreign currency, CV. MXY must pay attention to the foreign exchange loss factor. How this can be minimized, for example by hedging the exchange rate.

\section{CONCLUSIONS AND RECOMMENDATIONS}

Based on the results of the study, the following conclusions are obtained :

1. Business model canvas which is ideal for applying to CV. MXY can be seen as in figure 1.

Figure 1. Business Model Canvas CV. MXY

\begin{tabular}{|l|l|l|l|l|}
\hline Key Partners & Key Activities & Value Propositions & Customer Relationships & Customer Segments \\
\hline -Supplier & -Procurement & -One stop shopping & -Discount program & -Supplier \\
-Forwaders & -Sales & -Value of trust & -Souvenir free & -End user, focuses on \\
-Manufacturing & -Delivery & -Good customer & -Customer Relationship & marine industry, \\
partner & -Billing & service support & Management (CRM) & rental company, and \\
-Importing & Key Resources & \multirow{2}{*}{-Warranty product } & Channels & mining company \\
\cline { 2 - 2 } Partner & -Physical Asset & & -Own distribution facility &
\end{tabular}




\begin{tabular}{|c|c|c|c|}
\hline & $\begin{array}{l}\text {-Human } \\
\text { resources } \\
\text {-Green line } \\
\text { import facility }\end{array}$ & $\begin{array}{l}\text { and use forwaders } \\
\text {-Direct communication } \\
\text { by phone, e-mail, etc } \\
\text {-Promotion by social } \\
\text { Media } \\
\text {-Online platform }\end{array}$ & \\
\hline \multicolumn{2}{|l|}{ Cost Structure } & \multicolumn{2}{|l|}{ Revenue Streams } \\
\hline \multicolumn{2}{|c|}{$\begin{array}{l}\text {-Operational cost } \\
\text {-Merchandise procurement } \\
\text {-Income and import duties tax } \\
\text {-Shipping cost } \\
\text {-Promotional } \\
\text { cost }\end{array}$} & \multicolumn{2}{|c|}{-Spare parts sale in cash and credit } \\
\hline
\end{tabular}

2. Based on the identification of the existing elements it can be concluded that the business model canvas is basically a solution that is quite simple and easy to understand as a first step in making a business model for small and medium-sized companies. This is in line with research Ching (2013), Umar (2018).

Recommended research results on the business model CV. MXY has been stated in the results and analysis. With respect to the results of the recommendations given, it is expected that CV. MXY can conduct periodic reviews of its business model. The business model canvas that can be used by novice entrepreneurs and their compilation is growing with their use, they can use variations that are more in line with their business, Ching (2013).

The business world is very dynamic and very fast changing at the present time. For this reason, further research is needed to see whether this business model is suitable for family businesses, by looking at applications, implementations, other parameters and other family businesses. The results of this study cannot be generalized to others companies, because to be implemented it need further study.

\section{REFERENCES}

Ali, H., Limakrisna, N. (2015). Metodologi Penelitian. Yogyakarta : Penerbit Deepublish.

Ali, H. (2020). Modul Mata Kuliah Strategic Management. Jakarta : Universitas Mercu Buana.

Ching, H.Y., Fauvel, C. (2013). Criticisms, Variations And Experiences With Business Model Canvas. International Journal of Small Business and Entrepreneurship Research Vol.1. No.4, pp. 18-29.

Haryanto, A.T. (2020). https://inet.detik.com/cyberlife/d-4907674/riset-ada-1752-jutapengguna-internet-di-indonesia. (13 Mei 2020 jam 16.25).

Kaur, Raghuveer. (2018). Corporate Governance in Family Businesses - A Review. Pacific Business Review International Volume 11 Issue 5, November 2018.

Osterwalder, A., Pigneur, Y., \& Clark, T.(2010). Business model generation: A Handbook For Visionaries, Game Changers, and Challengers. New Jersey : Wiley Publishing. 
Putri, V. M. (2020). https://inet.detik.com/cyberlife/d-4906129/53-penduduk-indonesiasudah-belanja-online. (13 Mei 2020 jam 16.30)

Tim PPM Manajemen. (2012). Business Model Canvas : Penerapan di Indonesia. Jakarta : PPM.

Umar, A., Sasongko, H., Aguzman, G., Sugiharto. (2018). Business Model Canvas As A Solution For Competing Strategy Of Small Business In Indonesia. International Journal of Entrepreneurship Volume 22, Issue 1, 2018.

Wijaya, L.E., Indriyani, R. (2016). Analisis Business Model Canvas Pada CV. Kayu Murni Surabaya. Jurnal AGORA Vol. 4, No. 2. 